\title{
Differential Survival of Cajal-Retzius Cells in Organotypic Cultures of Hippocampus and Neocortex
}

\author{
José A. Del Río, ${ }^{1,2}$ Bernd Heimrich,, ${ }^{2}$ Hans Supèr, ${ }^{1}$ Víctor Borrell, ${ }^{1}$ Michael Frotscher, ${ }^{2}$ and Eduardo Soriano ${ }^{1}$ \\ ${ }^{1}$ Department of Animal and Plant Cell Biology, Faculty of Biology, University of Barcelona, 08028 Barcelona, Spain, and \\ 2Institute of Anatomy, University of Freiburg, D-79001 Freiburg, Germany
}

Cajal-Retzius (CR) cells are transient, pioneer neurons of layer I of the cortex that are believed to play essential roles in corticogenesis, e.g., in neuronal migration and synaptogenesis. Here we have used calretinin immunostaining to study the characteristics, survival, and fate of CR cells in single organotypic slice cultures of mouse neocortex and hippocampus deprived of their extrinsic afferents. In neocortical explants, CR cells were observed after 1-3 d in vitro (DIV), but they disappeared after 5-7 DIV, which is similar to their time of degeneration in vivo. The disappearance of CR cells in neocortical slices was prevented by incubation with tetrodotoxin and the glutamate receptor antagonist 6-cyano-7-nitroquinoxaline2,3,-dione but not by 2-amino-5-phosphonopentanoic acid, suggesting that neuronal activity and non-NMDA glutamate receptors may trigger $\mathrm{CR}$ cell death in the neocortex.

In contrast to the situation in vivo, in which many hippocampal CR cells disappear at approximately the third postnatal week, CR cells survived in single hippocampal cultures after long incubation times (31 DIV), with their morphology essentially unaltered. In contrast, fewer CR cells were found when hippocampal slices were cocultured with explants from the entorhinal cortex. Because CR cells are transient synaptic targets for entorhinohippocampal afferents, these findings suggest a role for entorhinal afferents in the degeneration of CR cells in the hippocampus. In conclusion, this study shows different survival properties of CR cells in organotypic slice cultures of hippocampus and neocortex, and it suggests that different mechanisms are involved in the regulation of the process of naturally occurring $\mathrm{CR}$ cell death in the two cortical regions.

Key words: Cajal-Retzius cells; cortical development; neuronal death; neuronal activity; calretinin; organotypic cultures; mouse
During the development of the mammalian cerebral cortex, the earliest postmitotic neuroblasts form the primordial plexiform layer or preplate. Subsequent neurons settle in the cortical plate, which splits the preplate population into the marginal zone and the subplate layer (Marín-Padilla, 1972; De Carlos and O'Leary, 1992; Valverde et al., 1995b). Subplate neurons play important roles in the establishment and reshaping of cortical connections, in particular of thalamocortical afferents (Shatz et al., 1988; McConnell et al., 1989; Ghosh et al., 1990; Ghosh and Shatz, 1992; De Carlos and O’Leary, 1992; Allendoerfer and Shatz, 1994). Later, most subplate cells disappear by cell death in kittens and primates, whereas their loss is less dramatic in rodents, with many of them contributing to the formation of layer $\mathrm{VIb}$ in the adult (Luskin and Shatz, 1985; Valverde and Facal-Valverde, 1987, 1988; Shatz et al., 1988; Al-Ghoul and Miller, 1989; Valverde et al., 1989, 1995a; Kostovic and Rakic, 1990; Bayer and Altman, 1990, 1991; Woo et al., 1991). The main representatives of the marginal zone-layer I are the Cajal-Retzius (CR) cells. These early-generated neurons have a characteristic subpial location, large perikarya with long horizontal dendrites, and axonal

Received March 18, 1996; revised Aug. 1, 1996; accepted Aug. 12, 1996.

This work was supported by grants from the Deutsche Forschungsgemeinschaft (SFB 505, Leibniz Program), the Spanish Ministry of Education (SAF94-743), the Spanish Ministry of Health (FIS93-369), and the Catalonian Government (QR95/ 564). J.A.D.-R. was supported by a short-term fellowship from the Catalonian Government (BE94-3/634). We thank C. Hofmann and Albert Martínez for technical assistance, and Robin Rycroft for linguistic advice.

Correspondence should be addressed to Dr. Eduardo Soriano, Department of Animal and Plant Cell Biology, Faculty of Biology, University of Barcelona, Avenue Diagonal 645, 08028 Barcelona, Spain.

Copyright (C) 1996 Society for Neuroscience $0270-6474 / 96 / 166896-12 \$ 05.00 / 0$ arbors that remain restricted to layer I. During postnatal development, most CR cells are likely to undergo cell death, although some may remain in the adult or be transformed into nonpyramidal neurons (Marín-Padilla, 1971, 1984, 1990; Bradford et al., 1977; König et al., 1977; Rickmann et al., 1977; König and Marty, 1981; Edmunds and Parnavelas, 1982; Marín-Padilla and MarínPadilla, 1982; Parnavelas and Edmunds, 1983; Derer and Derer, 1990, 1992; Huntley and Jones, 1990; Del Río et al., 1995a).

Although there are many studies on CR cells, their developmental functions and the mechanisms regulating their disappearance are largely unknown. Because of their strategic location in layer I, it has been suggested that CR cells might play a role in neuronal migration (Marín-Padilla, 1988; Del Río et al., 1995a). This notion is supported by recent data showing that the gene disrupted in the reeler mutant mouse is expressed by CR cells and that inhibition of its encoded protein perturbs the histotypic organization in reaggregation cultures (D'Arcangelo et al., 1995; Hirotsune et al., 1995; Ogawa et al., 1995). In addition, CR cells are also found in the developing hippocampus, where they are transient synaptic targets for ingrowing entorhinal afferents (Soriano et al., 1994; Supèr and Soriano, 1994; Del Río et al., 1995b).

Organotypic slice cultures provide a useful model for addressing developmental questions, because the cytoarchitectonics and intrinsic connectivity are preserved to a large extent. Furthermore, organotypic cultures are well suited for determining whether certain characteristics and developmental events are determined intrinsically (Frotscher et al., 1990, 1995; Caeser and Schütz, 1992; Frotscher and Heimrich, 1993; Gillies and Price, 1994; Rennie et al., 1994; Tuttle et al., 1995). To gain more 
information on the developmental roles of CR cells and on the mechanisms responsible for their degeneration, we have studied here the morphological features, survival properties, and fate of CR cells in single organotypic slice cultures from the somatosensory cortex and hippocampus, deprived of their extrinsic afferent inputs. We used calretinin immunostaining to label CR cells, because in the mouse this calcium-binding protein is present in CR cells throughout their life (Del Río et al., 1995a). We found that CR cells in neocortical cultures disappear with a temporal sequence reminiscent of that found in vivo, whereas these neurons persist in hippocampal slice cultures even after long incubation times. Moreover, experiments with ion-channel antagonists suggest that the degeneration of CR cells in the neocortex depends on neuronal activity and non-NMDA glutamate receptors. In contrast, many hippocampal CR cells disappear in entorhinohippocampal cocultures, suggesting a role for entorhinal afferents in the degeneration of these pioneer neurons.

\section{MATERIALS AND METHODS}

Single organotypic slice cultures. Hippocampal and neocortical slice cultures were prepared from day of birth (P0) or P1 mouse pups (NMRI; Charles River Wiga, Sulzfeld, Germany) essentially as described (Caeser and Schütz, 1992; Frotscher and Heimrich, 1993). Animals were anesthetized by hypothermia, their brains were aseptically removed, and the hippocampus and prospective parietal cortex were dissected out under microscopic control. Tissue pieces were cut into transverse slices (300$400 \mu \mathrm{m}$ thick) using a Mcllwain tissue chopper, and they were maintained in Gey's balanced salt solution supplemented with glucose $(6.5 \mathrm{mg} / \mathrm{ml})$ for $40 \mathrm{~min}$ at $4^{\circ} \mathrm{C}$. Then, selected slices were cultured using either the roller tube or the membrane interphase techniques (Gäwhiler, 1981, 1984; Stoppini et al., 1991). For the roller tube technique, hippocampal and neocortical explants $(n=142)$ were placed onto coverslips and embedded in a clot of heparinized chicken plasma (Cocalico Biologicals, Reamstown, PA) coagulated with thrombin. Thereafter, coverslips were placed into planar tubes containing $0.5 \mathrm{ml}$ of culture medium composed of $50 \%$ Eagle's basal medium, 25\% HBSS, 25\% heat-inactivated horse serum, and $2 \mathrm{~mm}$ glutamine and glucose $(6.5 \mathrm{mg} / \mathrm{ml})$ and incubated in a rotating drum at $36^{\circ} \mathrm{C}$ in dry air. Alternatively, slices $(n=126)$ were placed on 30 $\mathrm{mm}$ sterile membranes (Millicell-CM, Millipore, Bedford, MA) and transferred into six-well tissue culture trays. Cultures were fed with $0.8 \mathrm{ml}$ of culture medium $(50 \%$ minimal essential medium, $25 \%$ horse serum, $25 \%$ HBSS) containing $2 \mathrm{~mm}$ glutamine and $0.044 \% \mathrm{NaHCO}_{3}$ adjusted to $\mathrm{pH}$ 7.3. The membrane cultures were maintained in a humidified incubator at $36^{\circ} \mathrm{C}$ in $5 \% \mathrm{CO}_{2}$.

Immunocytochemical techniques. For light microscopy analyses, cultures were fixed after several periods of incubation $[1,3,5,7,10,15,21$, and $31 \mathrm{~d}$ in vitro (DIV)] with $0.1 \mathrm{M}$ phosphate-buffered $4 \%$ paraformaldehyde for $4 \mathrm{hr}$ at $4^{\circ} \mathrm{C}$. After several rinses in $0.1 \mathrm{~m} \mathrm{PBS}, 40-\mu \mathrm{m}$-thick horizontal sections were obtained with a vibratome. To enhance the penetration of immunoreagents, free-floating sections were incubated in a graded series of dimethyl sulfoxide (DMSO) $(5,10,20$, and $40 \%$ in 0.1 M phosphate buffer for 10 min each). After they were washed in PBS, sections were blocked with $10 \%$ normal goat serum and incubated with a well characterized rabbit polyclonal antibody against human recombinant calretinin (dilution 1:2000) (Schwaller et al., 1993) for $2 \mathrm{~d}$ at $4^{\circ} \mathrm{C}$. Tissue-bound primary antibody was detected using the avidin-biotinperoxidase complex (ABC) as indicated by the manufacturer (Vector Labs, Burlingame, CA). Immunoreagents were diluted in PBS containing $0.5 \%$ Triton X-100, $0.2 \%$ gelatin, and $5 \%$ preimmune goat serum. After development with $0.03 \%$ diaminobenzidine (DAB) and $0.01 \% \mathrm{H}_{2} \mathrm{O}_{2}$, sections were mounted onto gelatinized slides, dehydrated in ethanol, and coverslipped with Eukit. Cocultures of entorhinal cortex and hippocampus were processed similarly (see below). Immunocytochemical controls, including omission of the primary antibody or its substitution by normal rabbit serum, prevented immunostaining. Additional sections were stained with cresyl violet.

For electron microscopy, cultures were fixed with $4 \%$ paraformaldehyde, $0.1 \%$ glutaraldehyde, and $15 \%$ saturated picric acid dissolved in 0.1 $\mathrm{m}$ phosphate buffer, $\mathrm{pH}$ 7.4. Vibratome sections were processed for the visualization of calretinin as described above, except that the DMSO treatment and Triton X-100 were omitted. After the immunoperoxidase reaction, sections were post-fixed with $2 \%$ osmium tetroxide, stained with uranyl acetate, and flat-embedded in epon (TAAB). After photodocumentation, selected cells were reembedded and sectioned on a Reichert ultratome. Thin sections were mounted onto Formvar-coated slot grids and examined in the electron microscope.

To allow comparison with the situation in vivo, several series of brain sections from postnatal animals were processed for calretinin immunostaining. After ether anesthesia, postnatal mice (P0, P2, P3, P5, P8, P10, $\mathrm{P} 15$, and P21, as well as young adults; two each) were perfused through the ascending aorta with $4 \%$ paraformaldehyde. After overnight postfixation, horizontal or coronal vibratome sections ( $40 \mu \mathrm{m}$ thick) were processed for the immunocytochemical detection of calretinin, as described previously (Del Río et al., 1995a).

Tetrodotoxin $(T T X)$ and glutamate receptor antagonist treatments. After 2 DIV, neocortical slices (12-14 each) were incubated with culture medium to which either TTX $\left(10^{-2} \mu \mathrm{M}\right.$; Sigma, Poole Dorset, UK) or the glutamate receptor antagonists 2-amino-5-phosphonopentanoic acid (AP-5) (40 $\mu \mathrm{M}$; Research Biochemicals, Natick, MA) or 6-cyano-7nitroquinoxaline-2,3-dione (CNQX) (10 $\mu \mathrm{M}$; Research Biochemicals) was added. Culture medium containing these agents was changed every day. Control slices were cultured in parallel, but TTX and glutamate receptor antagonists were omitted. After 8 DIV, cultures were processed for the immunocytochemical visualization of calretinin, as described above. The number of calretinin-positive CR cells in layer I was counted in $250 \mu \mathrm{m}$ horizontal stripes, using a $40 \times$ oil-immersion objective and a millimetric eyepiece. Six to eight cultures were harvested for each treatment $(6-10$ samples each). Crude cell counts were then corrected according to Abercrombie (1946).

In situ labeling of DNA fragmentation. For the in situ DNA nick-end labeling technique, cultures were fixed after 7, 10, and 15 DIV with phosphate-buffered $4 \%$ paraformaldehyde for $2 \mathrm{~d}$ at $4^{\circ} \mathrm{C}$. Vibratome sections ( $30 \mu \mathrm{m}$ thick) were mounted onto poly-L-lysine-coated slides and dried overnight at $30^{\circ} \mathrm{C}$. Thereafter, sections were processed by the Terminal Transferase (TdT)-mediated d-UTP nick-end labeling technique (TUNEL) as described (Gravieli et al., 1992). Briefly, sections were sequentially incubated with proteinase $\mathrm{K}(20 \mu \mathrm{M} / \mathrm{ml})$ for $20 \mathrm{~min}$ at room temperature and with TdT ( 0.3 Ehrlich units/ $\mu$ l) and biotinylated dUTP in TdT buffer in a humidified chamber at $37^{\circ} \mathrm{C}$ for $90 \mathrm{~min}$. After they were washed, the sections were incubated with $2 \%$ bovine serum albumin $(1$ $\mathrm{hr}$ ) and the $\mathrm{ABC}$ complex (dilution 1:100; $2 \mathrm{hr}$ ). Peroxidase was developed with $0.03 \%$ DAB, $0.2 \%$ nickel ammonium sulfate, and $0.01 \% \mathrm{H}_{2} \mathrm{O}_{2}$ (Hancock, 1982). Sections were counterstained with hematoxylin, dehydrated, and coverslipped with Eukit.

Entorhinohippocampal coculture experiments. Cocultures were prepared from $\mathrm{P} 0-\mathrm{P} 1$ mice $(n=55)$. Single horizontal sections containing both the entorhinal cortex and the hippocampus, or alternatively, randomly pooled slices of hippocampus and entorhinal cortex, were cultured as described (Frotscher and Heimrich, 1993; Li et al., 1993, 1994). Cocultures of two hippocampal slices were also prepared $(n=34)$. Cocultures were fixed after 5-7, 10-15, and 17-21 DIV and processed for calretinin immunocytochemistry. To assess the formation of entorhinohippocampal connections, a crystal of biocytin was injected in some cocultures in the entorhinal slice $24 \mathrm{hr}$ before fixation (Frotscher and Heimrich, 1993). Biocytin anterograde labeling was visualized using the $\mathrm{ABC}$ complex and a nickelenhanced $\mathrm{DAB}$ reaction.

The number of calretinin-positive CR cells present in the stratum lacunosum-moleculare/outer molecular layer of single hippocampal cultures, as well as of entorhinohippocampal and double hippocampal cocultures, was counted in $25,000 \mu \mathrm{m}^{2}$ samples using a $40 \times$ oil-immersion objective and a millimetric eyepiece (five to seven cultures at each stage, three to six samples per culture). Counts were corrected according to Abercrombie (1946).

\section{RESULTS}

\section{Postnatal evolution of Cajal-Retzius cells in vivo}

At early postnatal stages (P0-P5), CR cells were packed densely in layer I of the neocortex, where they were recognized by their characteristic morphology (Fig. 1A,C). CR cells displayed large, ovoid perikarya from which thick horizontal dendrites with vertical extensions originated. Later (P8-P10) there was a dramatic decrease in the number of $\mathrm{CR}$ cells, and very few calretininpositive cells were present in layer I at P21 (Fig. 1B) or in the adult neocortex. Shrunken, immunoreactive perikarya with atro- 

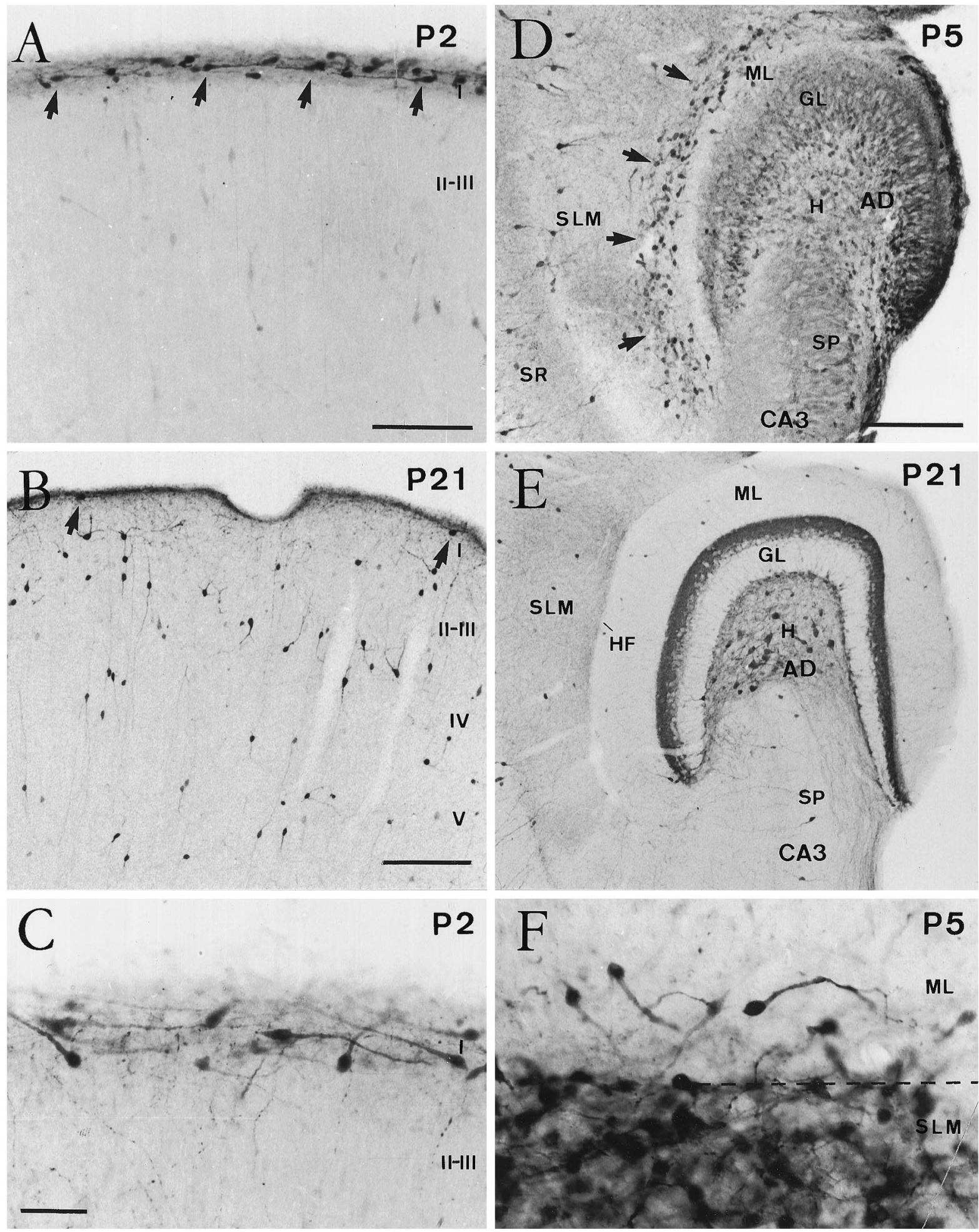

Figure 1. Postnatal evolution of calretinin immunostaining in the developing neocortex and hippocampus. $A$, $B$, Coronal sections of the neocortex at $\mathrm{P} 2$ $(A)$ and $\mathrm{P} 21(B)$. Although at $\mathrm{P} 2(A)$ numerous Cajal-Retzius cells (arrows) were present in layer $\mathrm{I}$, at $\mathrm{P} 21(B)$ calretinin-positive cells in this layer were seen only rarely (arrows). In contrast, the number of calretinin-positive nonpyramidal neurons in layers II-V increased notably at P21. $C$, High-power photomicrograph showing the typical monopolar morphology of Cajal-Retzius cells in layer I at P2. D, E, Horizontal sections of the hippocampus at P5 $(D)$ and P21 (E). At P5, Cajal-Retzius cells (arrows) are abundant near the hippocampal fissure, in the outer stratum lacunosum-moleculare (SLM), and in the adjacent aspect of the dentate molecular layer $(M L)$. Immature granule cells in the granule cell layer $(G L)$ displayed weak calretinin immunolabeling. At P21 $(E)$, very few calretinin-positive neurons could be seen near the hippocampal fissure $(H F)$. Detail shows densely packed Cajal-Retzius cells around the hippocampal fissure (dashed line) at P5. I-V, Cortical layers I-V; $S R$, stratum radiatum; $H$, hilus; $S P$, stratum pyramidale; $C A 3$, hippocampal region CA3; $A D$, area dentata. Scale bars: $A, 100 \mu \mathrm{m} ; B, 150 \mu \mathrm{m}$, also pertains to $E ; C, 50 \mu \mathrm{m}$, also pertains to $F ; D, 150 \mu \mathrm{m}$. 


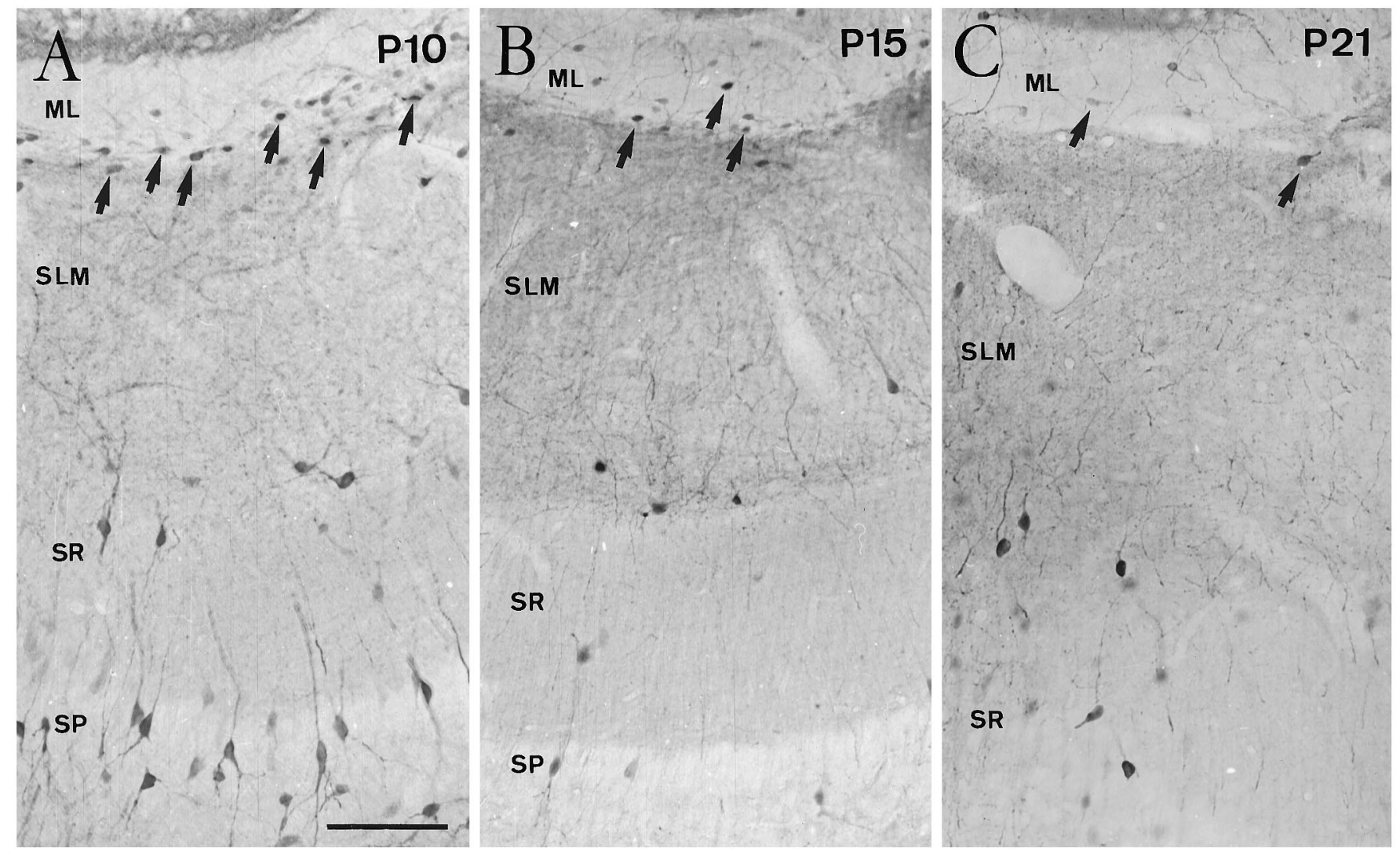

Figure 2. Evolution of Cajal-Retzius cells identified by calretinin immunolabeling in the late postnatal hippocampus. Although CR cells (arrows) are still abundant at P10 $(A)$ in the stratum lacunosum-moleculare $(S L M)$ and outer molecular layer $(M L)$, substantial numbers of cells are observed at P15 $(B)$ and fewer CR cells are present at P21 $(C)$. Abbreviations as in Figure 1. Scale bar (shown in $A$ ): $100 \mu \mathrm{m}$, also pertains to $B$ and $C$.

phic, swollen dendrites were observed in layer I at P5-P10, corresponding to degenerating CR cells (Del Río et al., 1995a).

In the hippocampus, CR cells at P0-P5 were located in the stratum lacunosum-moleculare of the hippocampus proper and in the outermost portion of the dentate molecular layer, near the hippocampal fissure (Fig. 1D). Hippocampal CR cells displayed a morphology similar to that in the neocortex (Fig. $1 F$ ). In both the neocortex and the hippocampus, some nonpyramidal neurons in different layers displayed calretinin immunolabeling (Fig. $1 A, B, D, E)$; in addition, immature granule cells in the dentate gyrus exhibited weak immunoreactivity during the postnatal period (Fig. 1D). The disappearance of calretinin-positive CR cells in the hippocampus occurred later than in the neocortex. Thus, although CR cells were still abundant at P10, substantial numbers were observed at P15; at P21, in contrast, the number of CR cells was markedly decreased (Fig. 2). At this stage and in adult mice, very few immunoreactive cells could be observed in the molecular layer of the dentate gyrus or in the stratum lacunosum-moleculare (Figs. $1 E, 2 C$ ). As in the neocortex, the remaining immunoreactive neurons displayed a morphology characteristic of nonpyramidal neurons.

\section{Evolution of CR cells in organotypic cultures}

In organotypic slice cultures, CR cells were identified at 1-3 DIV in both the hippocampus and neocortex on the basis of their distinctive shape and location as shown by calretinin immunostaining (Fig. 3). At longer incubation times, the evolution and fate of CR cells were different in cultures taken from these two cortical regions. No significant differences were observed in CR cell morphology or evolution when explants were cultured using the roller tube technique or the interphase membrane method.

\section{Neocortical cultures}

Soon after explantation (1-3 DIV), CR cells displayed a morphology reminiscent of that in vivo (Fig. $3 A, C$ ). On occasion, layer I expanded radially two to three times its thickness, and CR cells tended to appear loosely arranged (Fig. 3C). The number of CR cells in layer I declined dramatically at 5-7 DIV, and hardly any calretinin-positive cells with the distinctive morphological features of CR cells were observed in layer I beyond 10 DIV (Fig. 3B). The few immunoreactive neurons found in this layer after long incubation times (15-21 DIV) resembled the nonpyramidal cells described in the adult layer I in vivo. In addition, there were many other calretinin-immunoreactive nonpyramidal cells throughout the different layers in neocortical slice cultures (Fig. 3B).

Coincident with the decline in CR cells, we observed many calretinin-positive cells in layer I at 5-7 DIV displaying shrunken, atrophic cell bodies and swollen dendrites (Fig. $4 A$ ), suggestive of neuronal degeneration (Valverde and Facal-Valverde, 1987; Wahle and Meyer, 1987). At the electron microscope, these small perikarya showed dense heterochromatin granules and a disrupted fine structure of cytoplasmic organelles (Fig. 4B) similar to that described for degenerating CR cells in vivo (Del Río et al., 1995a). Examination of Nissl-stained sections from slice cultures revealed the virtual disappearance of large horizontal neurons in layer I at 10-15 DIV (Fig. 4E,F), suggesting than CR cells disappear from layer I rather than cease calretinin expression. To ascertain the degeneration of $\mathrm{CR}$ cells, organotypic slice cultures 

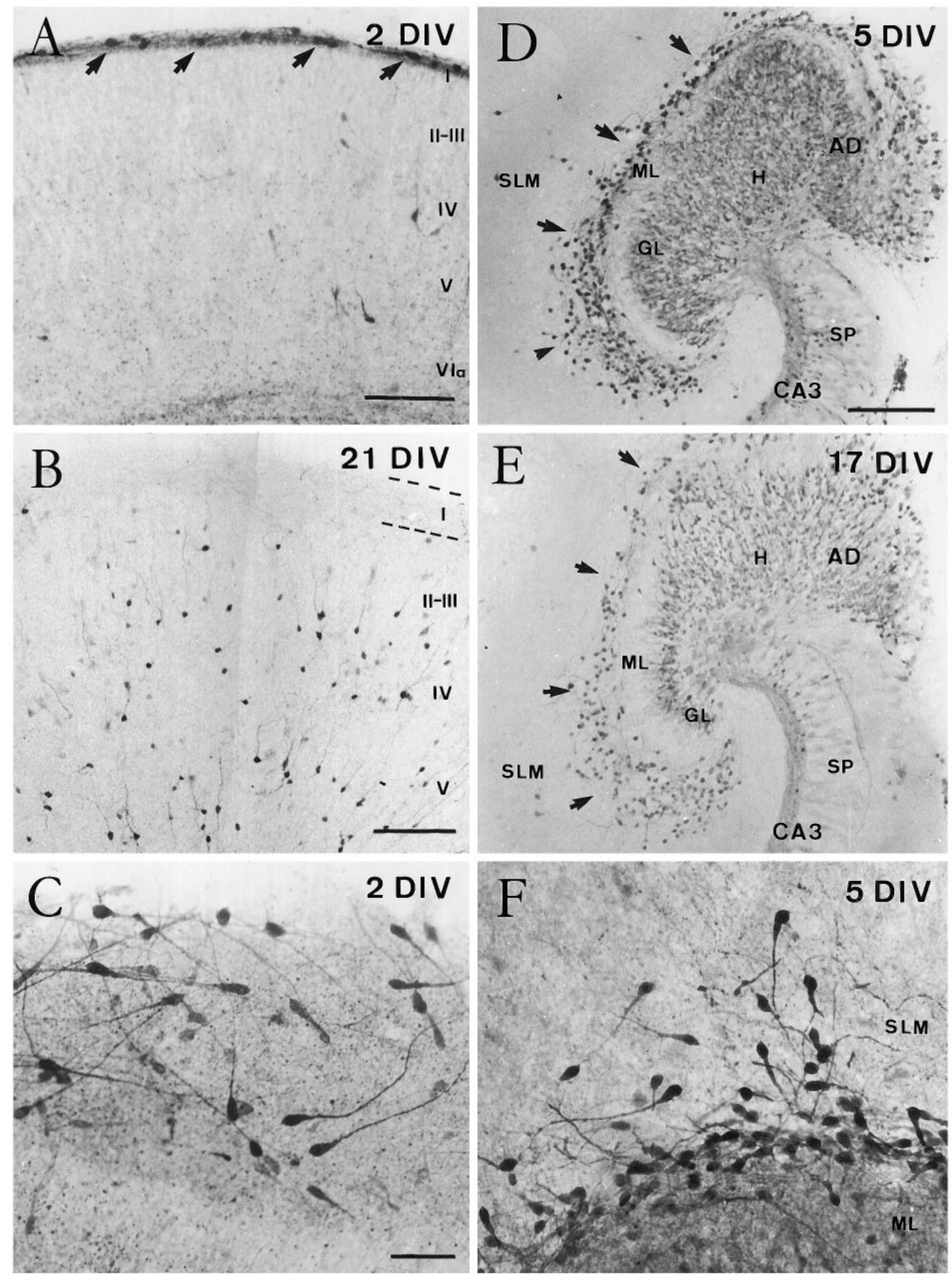

Figure 3. Evolution of Cajal-Retzius cells in organotypic slice cultures of the neocortex $(A-C)$ and hippocampus $(D-F)$ as shown by calretinin immunostaining. $A, B$, Cajal-Retzius cells (arrows) were seen in layer I in organotypic slices cultured for 2 DIV $(A)$ but were virtually absent after long incubation times $(B)$. Notice the increased immunolabeling of nonpyramidal neurons at 21 DIV. $C$, High magnification illustrating the morphological features of Cajal-Retzius cells after 2 DIV. $D, E$, Calretinin immunostaining in single organotypic slice cultures of hippocampus after $5(D)$ and $17(E)$ DIV. After both incubation times, Cajal-Retzius cells (arrows) were abundant in the molecular layer of the fascia dentata and in the stratum lacunosum-moleculare of the hippocampus proper. Weak immunolabeling was also seen in the granule cells and in the mossy fiber zone in CA3 region. $F$, High-magnification photomicrograph showing Cajal-Retzius cells in the stratum lacunosum-moleculare and in the dentate molecular layer of the hippocampus after 5 DIV. Abbreviations as in Figure 1. Scale bars: $A, 150 \mu \mathrm{m} ; B, 200 \mu \mathrm{m} ; C, 50 \mu \mathrm{m}$, also pertains to $F ; D, 200 \mu \mathrm{m}$, also pertains to $E$. 


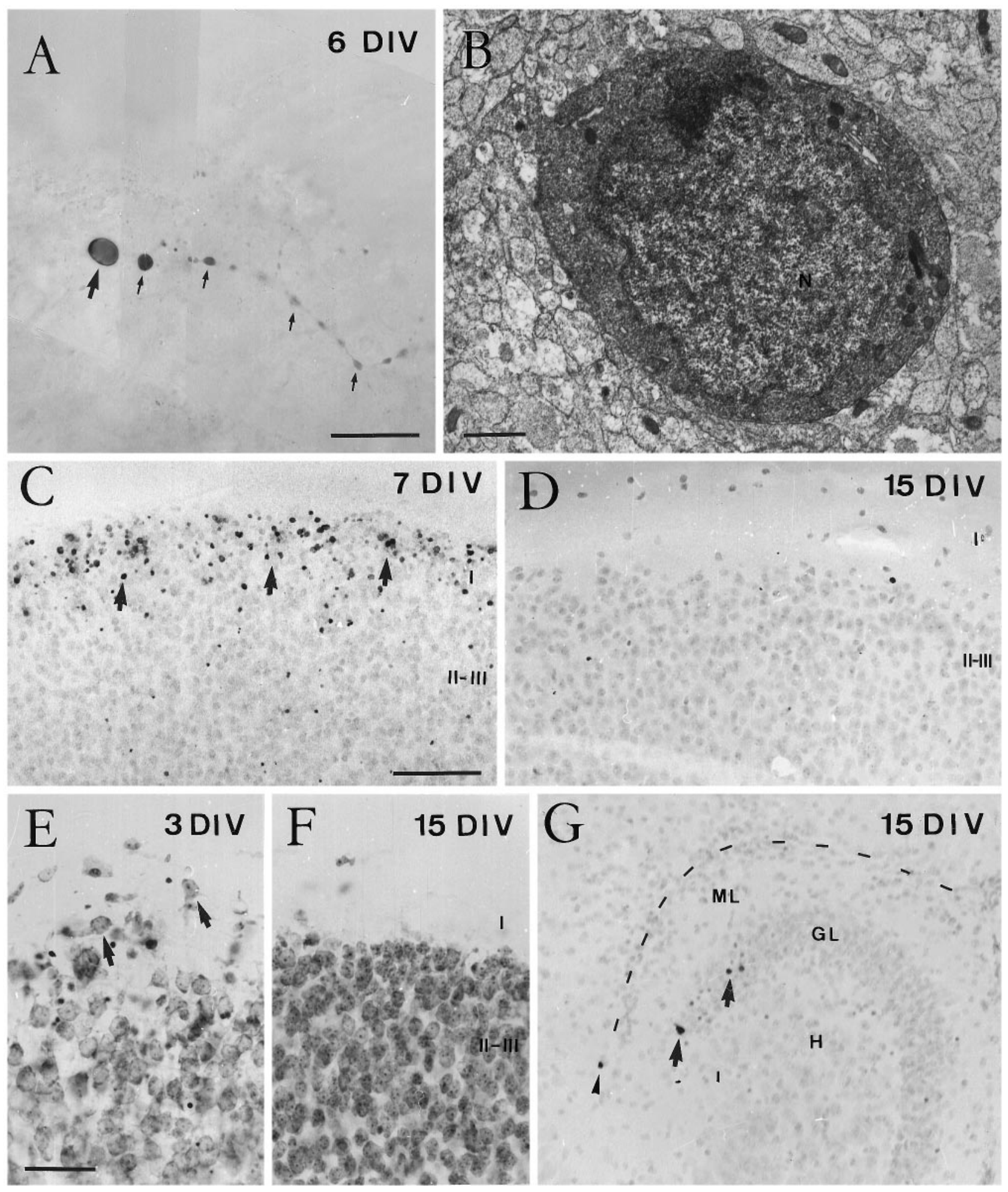

Figure 4. Degeneration of Cajal-Retzius cells in organotypic slice cultures of neocortex. $A, B$, Correlated light $(A)$ and electron microscopy $(B)$ of a presumedly degenerating Cajal-Retzius cell after 6 DIV. $A$, At the light microscope, a calretinin-positive Cajal-Retzius cell displays shrunken cell body (arrow) and a swollen dendrite (small arrows). B, Electron micrograph of the perikaryon of the cell in $A$, showing disrupted fine structure of cytoplasmic organelles and chromatin condensation in the nucleus $(N)$. $C, D$, Distribution of TUNEL-positive cells. In neocortical cultures, most TUNEL-positive cells (arrows) are present in layer I after 7 DIV $(C)$, whereas TUNEL-positive cells are absent from this layer at 15 DIV $(D)$. $E$, $F$, Distribution of Nissl-stained cell bodies in layer I of organotypic neocortical cultures. At short incubation times $(E)$, some neurons in layer I display large perikarya and shapes typical of CR cells (arrows), whereas at longer incubation times $(F)$ these large perikarya have disappeared from layer I. As in vivo, some pyknotic cells could also be noted at 3 DIV in layers II and III $(E)$. $G$, Distribution of TUNEL-positive cells in hippocampal cultures. These cells are found in the stratum lacunosum-moleculare only very exceptionally, whereas some labeled neurons were observed in the granule cell layer (arrows). $C, D$, and $G$ are from sections counterstained with hematoxylin. Abbreviations as in Figure 1. Scale bars: $A, 25 \mu \mathrm{m} ; B, 1 \mu \mathrm{m} ; C, 100 \mu \mathrm{m}$, also pertains to $D$ and $G ; E, 50$ $\mu \mathrm{m}$, also pertains to $F$. 


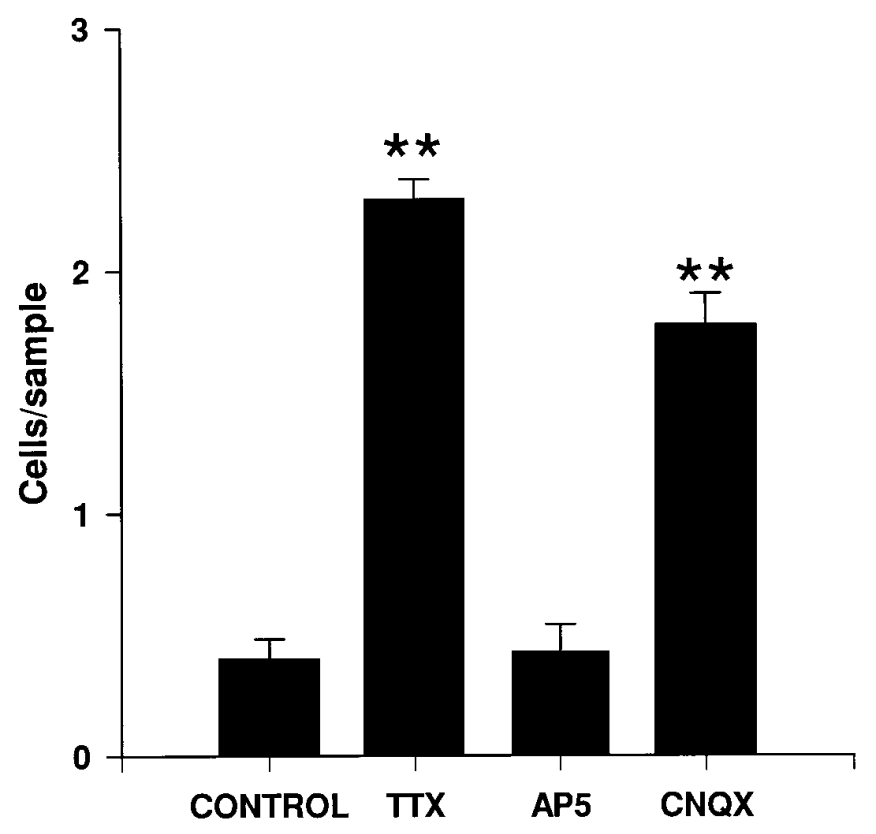

Figure 5. The number of Cajal-Retzius cells present in layer I (number of cells per $250 \mu \mathrm{m}$ horizontal stripe) in organotypic slice cultures of neocortex cultured for $10 \mathrm{DIV}$, after chronic treatment with $T T X, A P 5$, or $C N Q X$, as well as in control slices (mean $\pm \mathrm{SEM}$ ). Significant differences $\left({ }^{* *} p \leq 0.01\right.$; ANOVA, Scheffe's test) compared with controls were found after TTX and CNQX treatments.

were processed for the detection of DNA fragmentation. A large number of TUNEL-positive nuclei were found in layer I after 5-7 DIV, whereas the remaining cortical layers were largely devoid of positive nuclei (Fig. 4C), indicating massive cell degeneration in layer I at these stages. In contrast, there was a virtual absence of TUNEL-positive nuclei in layer I at 10-15 DIV (Fig. 4D). Taken together, these data indicate that CR cells disappear in organotypic slice cultures of postnatal neocortex, most likely by cell degeneration, following a time schedule reminiscent of that in vivo.

To investigate the role of neuronal activity in the disappearance of CR cells, cortical explants were cultured with the $\mathrm{Na}^{+}$channel blocker TTX or with the NMDA and non-NMDA glutamate receptor antagonists AP-5 and CNQX, respectively (Fig. 5). Although AP-5 treatments did not significantly alter the number of CR cells, the survival of CR cells in layer I was increased sixfold by incubation with TTX and fourfold by incubation with CNQX. These results suggest that the disappearance of CR cells depends on neuronal activity mediated through non-NMDA-type glutamate receptors.

\section{Hippocampal cultures}

CR cells were found in hippocampal slice cultures after all incubation times (1-31 DIV), with their morphological features and distribution remaining essentially unaltered (Figs. 3D-F, 7C). As in vivo, $\mathrm{CR}$ cells were located in the stratum lacunosummoleculare of the hippocampus proper and in the outer molecular layer of the dentate gyrus, displaying typical monopolar shapes with a single, thick dendrite originating from one side of the perikaryon (Figs. $3 F, 7 C$ ). No significant differences were observed in CR cell numbers between short and long incubation times (Figs. 3D,E, 7C). The survival of CR cells in hippocampal slice cultures was supported by electron microscopy. Immunoreactive CR cells displayed large, healthy perikarya with numerous cytoplasmic organelles and a nucleus rich in euchromatin granules (Fig. 6A). Morphologically mature axon terminals established symmetric and asymmetric synaptic contacts on both the cell body and dendrites of CR cells (Fig. 6B). In addition, calretininimmunoreactive boutons, presumably originating from CR cells, were seen in the stratum lacunosum-moleculare to form asymmetric synaptic contacts with either immunopositive or unlabeled postsynaptic processes (Fig. 6C). The persistence of CR cells in vitro was also substantiated by experiments showing virtual absence of DNA fragmentation in the stratum lacunosum-moleculare/outer molecular layer in hippocampal slice cultures at 7-15 DIV (Fig. 4G). In contrast, occasional TUNEL-positive cells were observed in these cultures in the granular and pyramidal layers and in the stratum oriens (Fig. 4G). These findings suggest that most CR cells survive in single organotypic hippocampal cultures, in contrast to the situation in vivo.

During normal development, CR cells in the hippocampus are transient synaptic targets for developing entorhinal axons (Supèr and Soriano, 1994; Del Río et al., 1995b). We and others have found recently that the entorhinohippocampal connection can be reestablished in vitro with a high degree of specificity (Frotscher and Heimrich, 1993; Li et al., 1993; also see Fig. 7A) and that in entorhinohippocampal cocultures CR cells are also synaptic targets for ingrowing entorhinal axons (Del Río et al., 1995b). To ascertain whether these afferent fibers could influence CR cell survival, we cocultured slices of the entorhinal cortex and hippocampus and counted CR cells by calretinin immunostaining. After 10-21 DIV, most CR cells had disappeared from entorhinohippocampal cocultures (Figs. $7 B, 8$ ), with CR cell numbers being reduced by fourfold after 17-21 DIV, as compared with single hippocampal cultures (Figs. $7 C, 8$ ). In contrast, no significant differences were observed in double hippocampal cocultures (Fig. 8), where commissural connections are established (Frotscher and Heimrich, 1993; Frotscher et al., 1995).

\section{DISCUSSION}

In the present study, we have used calretinin immunostaining to label CR cells. This protein is present in the population of murine CR cells throughout their lives (Soriano et al., 1994; Del Río et al., 1995a; Liu et al., 1996), from embryonic day 11 (E11) (E. Soriano, J. A. Del Río, and S. Alcantara, unpublished observations) until many of them disappear at postnatal ages (Del Río et al., 1995a). Furthermore, calretinin expression is retained in CR cells in dissociated cultures (P. Derer, personal communication) and in organotypic slice cultures (Marty et al., 1996; present results), indicating that this protein is constitutively expressed in CR cells. Thus, calretinin antibodies seem to be excellent intrinsic cell markers for murine CR cells. The main results of the present study can be summarized as follows. (1) CR cells disappear, most likely by cell degeneration, in organotypic slice cultures of neocortex with a timing similar to that in vivo; (2) the disappearance of CR cells in neocortical slices is prevented by blockers of neuronal activity and by non-NMDA glutamate receptor antagonists; and (3) even after long incubation times, CR cells survive in single hippocampal cultures, whereas many of them disappear in entorhinohippocampal cocultures.

\section{Intrinsic determination of Cajal-Retzius cell fate in the neocortex}

The fate of CR cells has been controversial: cell dilution, neuronal death, or transformation into nonpyramidal neurons have been proposed (for review, see Marín-Padilla, 1984, 1988). At least in 

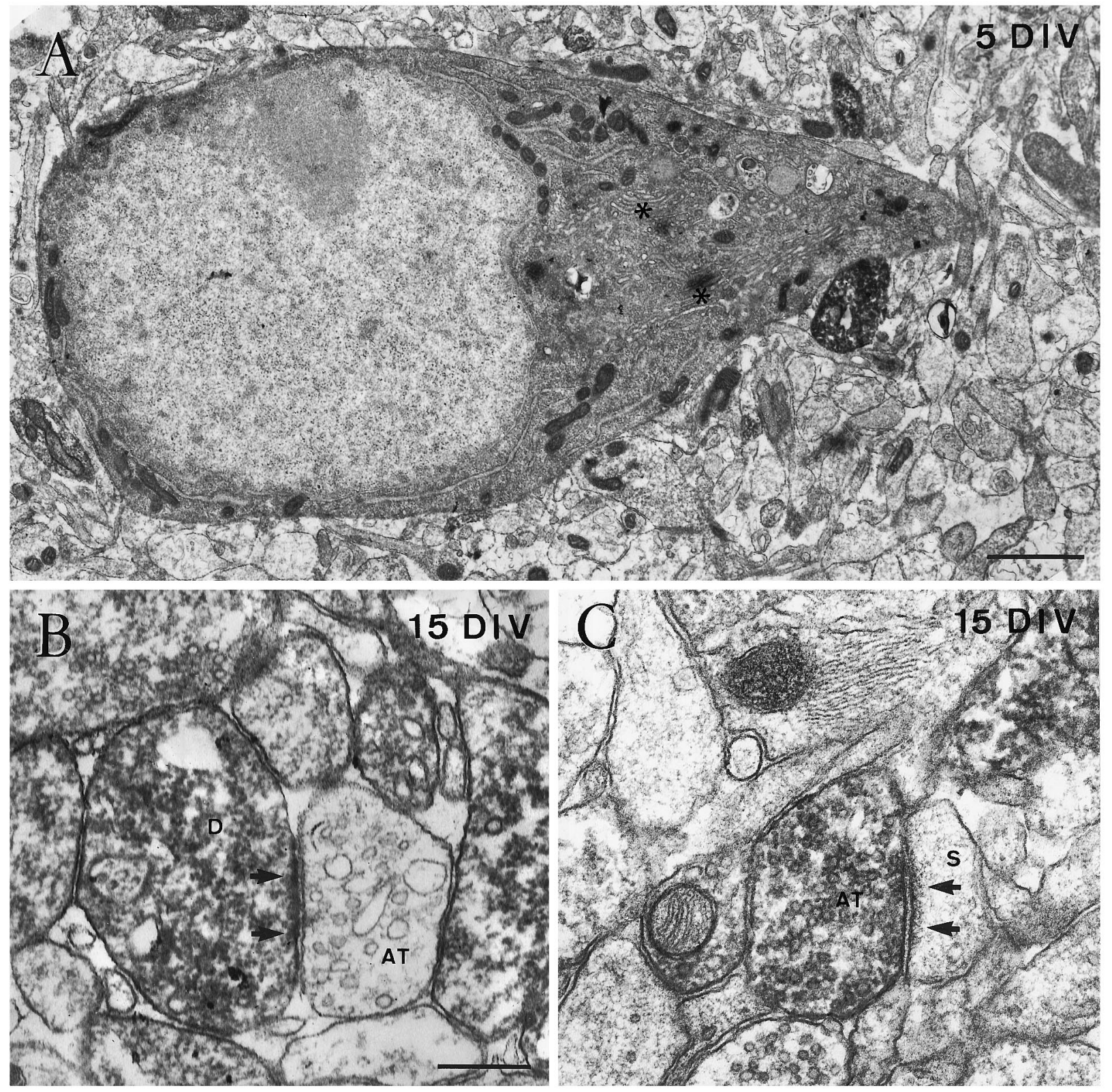

Figure 6. Fine structure of Cajal-Retzius cells in single hippocampal slice cultures, as shown by calretinin immunolabeling. $A$, Electron micrograph of the perikaryon of a Cajal-Retzius cell in the stratum lacunosum-moleculare after 5 DIV, showing a nucleus rich in euchromatin, a prominent nucleolus, and a cytoplasm rich in organelles such as the Golgi complex (asterisks). B, An immunopositive dendrite $(D)$ close to the hippocampal fissure receives an asymmetric synaptic contact (arrows) from an unlabeled axon terminal ( $A T$ ) after 15 DIV. $C$, Electron micrograph illustrating an immunoreactive axon terminal $(A T)$ in the stratum lacunosum-moleculare in asymmetric synaptic contact (arrow) with an unlabeled dendritic spine (S) at 15 DIV. Scale bars: $A, 1 \mu \mathrm{m} ; B, 0.4 \mu \mathrm{m}$, also pertains to $C$.

the murine neocortex, dilution at postnatal stages cannot account for the marked decrease in the number of CR cells (Del Río et al., 1995a). Some studies propose that CR cells may be GABAergic (Chronwall and Wolff, 1980); however, data from different cortical areas and in different animal species have shown that as defined by their characteristic morphology and subpial location, CR cells are non-GABAergic (Huntley and Jones, 1990; Derer and Derer, 1992; Soriano et al., 1994; Del Río et al., 1995a; Verney and Derer, 1995; Berger and Alvarez, 1996). This suggests that most GABA-positive neurons in layer I belong to a population of nonpyramidal neurons other than CR cells (Marín-Padilla, 1984). The possibility that CR cells might remain in the adult transformed into nonpyramidal GABAergic neurons (Parnavelas and Edmunds, 1983) also seems unlikely, because the GABApositive cells of the adult layer I are born throughout the entire period of cortical neurogenesis (Fairén et al., 1986), long after the early generation of CR cells (König et al., 1977; Raedler and Raedler, 1978; Bayer and Altman, 1990, 1991; Valverde et al., 1995b). The most likely fate of CR cells is cell degeneration, because (1) fate analyses using $\left[{ }^{3} \mathrm{H}\right]$ thymidine or $5^{\prime}$ bromodeoxyuridine (BrdU) show that most early-generated neurons of layer I are not present in late postnatal or adult cortex (Luskin and Shatz, 1985; Wood et al., 1992; Del Río et al., 1995a); (2) at the stages of disappearance, CR neurons display a morphology and fine structure typical of dying neurons (Derer and Derer, 1990; Del Río et al., 1995a); and (3) at postnatal stages we 

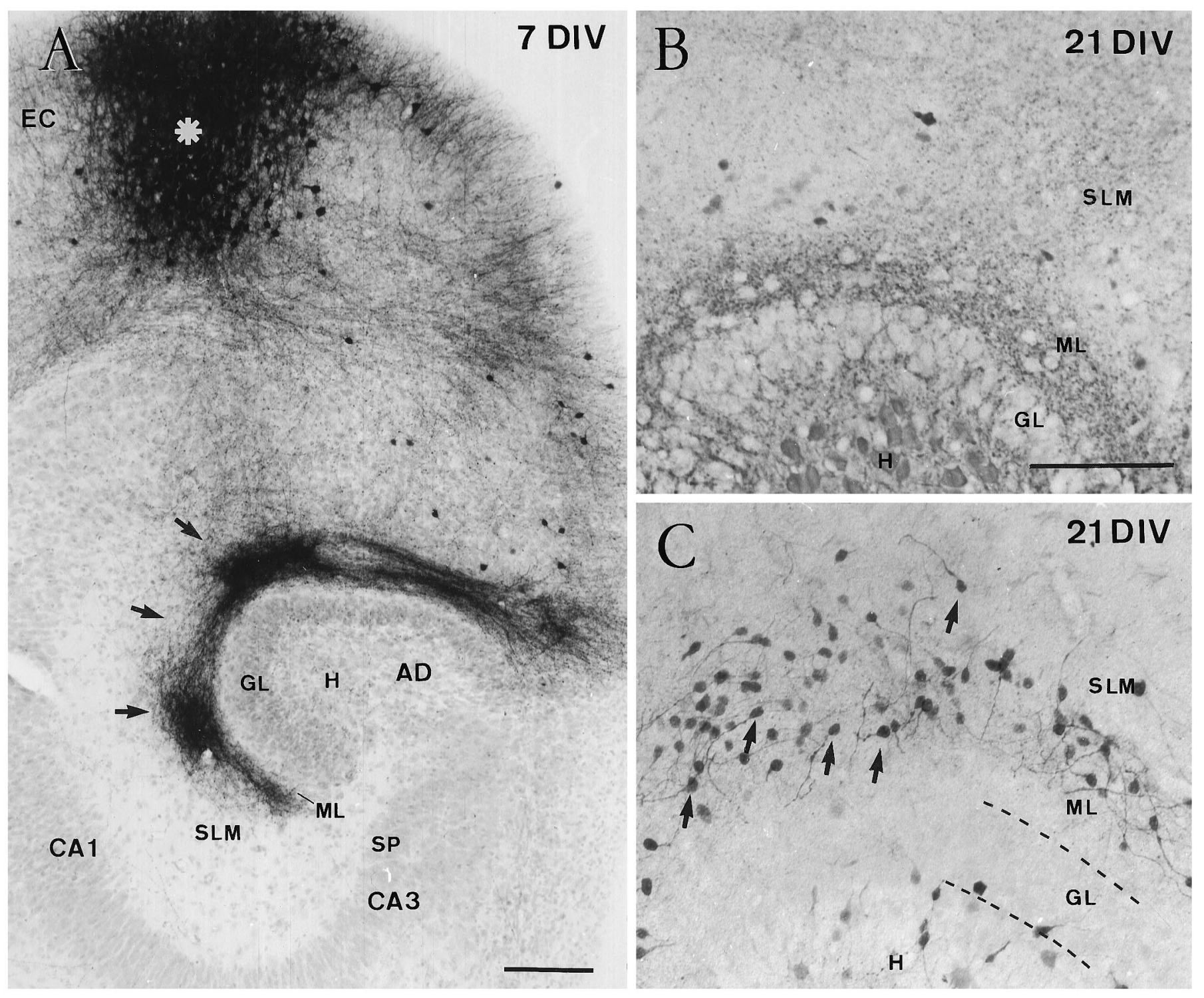

Figure 7. Reduction of hippocampal Cajal-Retzius cells in entorhinohippocampal cocultures. $A$, Low-power photomicrograph illustrating a typical entorhinohippocampal coculture after $7 \mathrm{DIV}$, in which entorhinal afferents to the hippocampus have been traced with biocytin. Section counterstained with hematoxylin. The injection site in the entorhinal cortex $(E C)$ is marked by an asterisk. Anterogradely labeled entorhinal fibers (arrows) were seen in the stratum lacunosum-moleculare and in the dentate molecular layer. $B, C$, Distribution of Cajal-Retzius cells in an entorhinohippocampal coculture $(B)$ and in a single hippocampal culture $(C)$ after 21 DIV. A marked reduction in the number of Cajal-Retzius cells was observed after coculturing the hippocampus and the entorhinal cortex $(B)$, whereas Cajal-Retzius cells (arrows) are abundant in single hippocampal slices $(C)$. Abbreviations as in Figure 1. Scale bars: $A, 100 \mu \mathrm{m} ; B, 200 \mu \mathrm{m}$, also pertains to $C$.

observed pyknotic nuclei in layer I that show BrdU immunostaining after pulses given at the earliest stages of neurogenesis, demonstrating that at least some early-generated neurons in layer I disappear by cell death (Del Río et al., 1995a). Thus, although a few CR cells might remain in the adult (Liu et al., 1996), most CR cells probably disappear by cell death.

In the murine neocortex, CR cells disappear during the beginning of the second postnatal week (Derer and Derer, 1990; Wood et al., 1992; Del Río et al., 1995a). The present study shows that CR cells in organotypic neocortical cultures taken from $\mathrm{P} 0-\mathrm{P} 1$ mouse pups disappear at 5-7 DIV, which closely corresponds to the sequence of disappearance in vivo. Furthermore, the observation of calretininimmunoreactive, degenerating CR neurons and of TUNEL-positive dying cells in layer I at the time of CR cell loss indicates that CR cells degenerate in neocortical slices as they do in vivo. This suggests that the factors triggering cell degeneration in normal development are retained in organotypic slices and are intrinsic to the cortex. The mechanisms that may be involved in naturally occurring cell death during development include (1) excitotoxic effects caused by afferents resulting in neuronal hyperexcitability (Choi, 1988; Oppenheim, 1991) and (2) competition for target-derived factors such as growth factors (Davies, 1988, 1994; Silos-Santiago et al., 1995). The present data showing that TTX and CNQX treatments decrease CR cell degeneration suggest a role for neuronal activity and non-NMDAtype glutamate receptors in the degeneration of CR cells in vitro. Furthermore, the early expression of AMPA/kainate glutamate receptors in layer I during development (H. Supèr, J. A. Del Río, A. Martínez, and E. Soriano, unpublished observations) suggests that these receptors are also involved in the degeneration of CR cells in normal corticogenesis. 


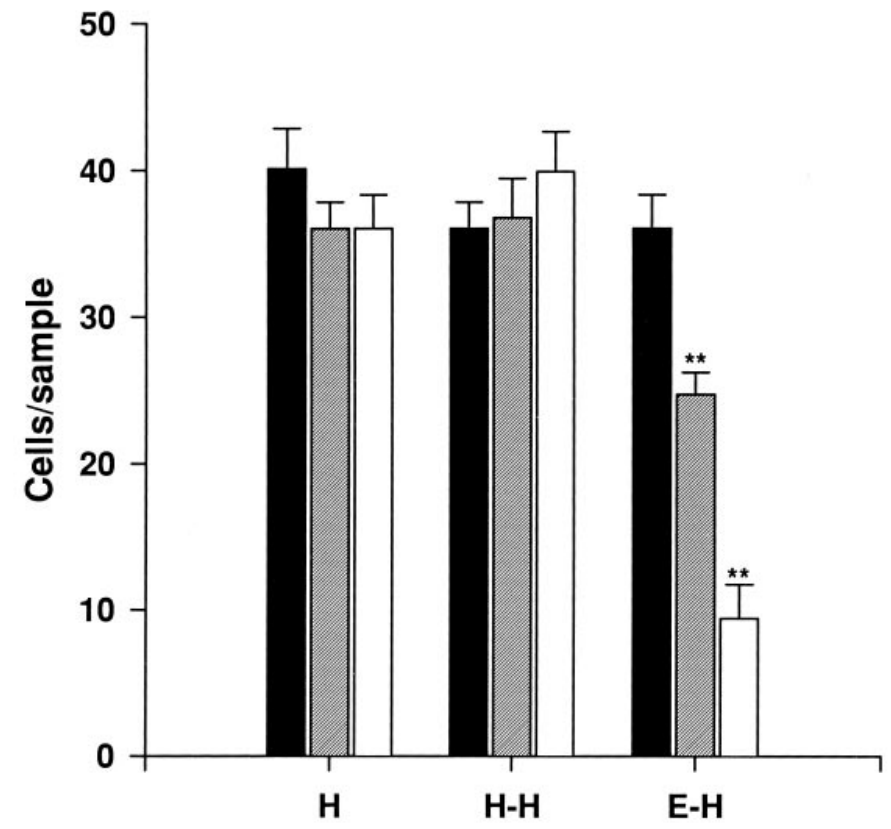

Figure 8. Number of Cajal-Retzius cells present in the stratum lacunosum-moleculare/molecular layer (number of cells per $25,000 \mu \mathrm{m}^{2}$ sample) in single organotypic hippocampal cultures $(H)$, double hippocampal cocultures $(H-H)$, and entorhinohippocampal cocultures $(E-H)$ after 5-7 DIV (black bars), 10-15 DIV (hatched bars), and 17-21 DIV (open bars) (mean \pm SEM). Significant differences compared with short incubation times (5-7 DIV) are found in entorhinohippocampal cocultures $\left({ }^{* *} p \leq\right.$ 0.01; ANOVA, Scheffe's test).

CR cells form morphologically mature synaptic contacts beginning at early developmental stages (Rickmann et al., 1977; Derer and Derer, 1990; Del Río et al., 1995a). Cortical afferents terminating in layer I, including thalamic axons and fibers from catecholaminergic and serotoninergic cell groups, are absent in organotypic cultures. Layer I also receives vertical connections from deep layers, especially from the subplate layer VIb (Divac et al., 1987; Valverde et al., 1989; Allendoerfer and Shatz, 1994). Because subplate cells survive in organotypic neocortical cultures (Bolz et al., 1992; Götz and Bolz, 1992), these vertical axons connecting the subplate to layer I are likely to be found in cultures and may be involved in the degeneration of CR cells. This notion is also supported by studies in vitro showing that CR cells survive in dissociated cultures taken from layer I (Derer and Derer, 1992) and in horizontal slice cultures cut through layer I (E. Soriano, R. M. Alvarado-Mallart, N. Dumesnil, J. A. Del Río, and C. Sotelo, unpublished observations), two conditions in which CR cells are cultured without connection to the subplate. These findings suggest that the factors determining the degeneration of CR cells in vitro are related to the maintenance of a laminated organotypic organization and to the preservation of the afferent connections arising from the subplate layer VIb.

A recent study reports that $C R$ cells express the trkB gene, the receptor for both brain-derived neurotrophic factor (BDNF) and neurotrophin 4 (NT4) (Pearlman et al., 1995). Expression of NT4 mRNA in the cortex is maximal at prenatal stages and declines thereafter (Timmusk et al., 1993). In contrast, levels of BDNF mRNA expression are low at prenatal stages and increase during postnatal development to maximal expression in adults (Friedman et al., 1991; Timmusk et al., 1994). Such a pattern of expression seems to argue against a function for this neurotrophic factor in sustaining CR cells. In addition, CR cells persist in the hippocampus of BDNF null-mutant mice, which also argues against this neurotrophin as a survival factor for CR cells (Marty et al., 1996). Additional analyses are needed to ascertain whether neurotrophins or other growth factors are involved in the regulation of CR cell survival and function.

\section{Degeneration of CR cells in entorhinohippocampal cocultures}

Here we show that CR cells survive in single hippocampal slice cultures, even after long incubation times, in contrast to the situation in vivo. This suggests that the factors determining the death of CR cells in vivo are absent in single organotypic hippocampal slices and are probably extrinsic to the hippocampus itself. In contrast to the neocortex, the subplate is poorly developed in the hippocampus (Nowakowski and Rakic, 1979; Kostovic et al., 1989; Soriano et al., 1994). The intrinsic connections of the developing hippocampus are largely unknown; however, ascending connections from the subplate to the marginal zone in this region, if present at all, might be less abundant than in the neocortex, which might explain why CR cells survive better in single hippocampal cultures than in neocortical slices.

In contrast, when hippocampal slices are cocultured with the entorhinal cortex, a large number of CR cells disappear, as in vivo. This process seems to be caused specifically by the entorhinal cortex, because CR cells do not disappear in double hippocampal cocultures. In entorhinohippocampal cocultures, entorhinal axons reach the target hippocampus by 3-4 DIV (Li et al., 1994; Del Río et al., 1995b), and as in vivo, CR cells in hippocampal organotypic cultures are transient synaptic targets for developing entorhinal axons (Supèr and Soriano, 1994; Del Río et al., 1995b), which may suggest a role for these fibers in the degeneration of CR cells. A recent study reports a $40 \%$ decrease in the number of CR cells in single hippocampal slices taken from 8-d-old rats (Marty et al., 1996). Such a decrease suggests that some CR cells may be committed to cell death at this explantation time, which is long after entorhinal fibers have reached the hippocampus (Supèr and Soriano, 1994). A major role of afferent fibers in naturally occurring cell death has been shown in other systems, such as the isthmo-optic and cochlear nuclei of the chick (Oppenheim, 1991). Moreover, entorhinal afferents influence the development and maturation of other hippocampal cell types (Mattson et al., 1988; Frotscher et al., 1995).

\section{Functions of CR cells and the maintenance of organotypic organization in cortical slices}

Recent studies have shown that reelin, the gene disrupted in the reeler mutation, is expressed by CR cells (D'Arcangelo et al., 1995; Hirotsune et al., 1995; Ogawa et al., 1995). Because reeler mice show abnormal migration and positioning in many brain regions, including neocortex and hippocampus (Caviness, 1973, 1982), the above studies suggested a role for CR cells in migration. In addition, we have recently seen that ablation of CR cells in newborn mice results in both abnormal migration and disruption of the radial glia scaffold (H. Supèr, J. A. Del Río, A. Martinez, and E. Soriano, unpublished observations) that subserves neuronal migration (Rakic, 1972), indicating that CR cells play a role in migration by regulating and sustaining the radial glia scaffold. Neuronal migration proceeds normally in organotypic cultures of neocortex shortly after explantation (1-3 DIV), whereas abnormal migration and positioning is observed after longer incubation 
times (Bolz et al., 1992; Götz and Bolz, 1992; Gillies and Price, 1994). This time sequence is coincident with the loss of CR cells in neocortical cultures reported here, which suggests that the survival of CR cells is essential for preserving neuronal migration in organotypic slices and more generally for preserving the histotypic, layered organization of neocortical slice cultures.

In the hippocampus, CR cells may also be involved in migration, because reeler mutant mice show severe malpositioning of hippocampal neurons (Caviness, 1973). In hippocampal slice cultures, the radial glia scaffold is preserved to a large extent, even after long incubation times (Del Río et al., 1991). Thus, the characteristic histotypic organization of hippocampal slice cultures may rely on the survival of CR cells in this region in vitro, which may guarantee the preservation of radial glia and the completion of migratory processes.

In conclusion, the present study has shown that CR cells have different fates and survival properties in the neocortex and hippocampus, suggesting that the mechanisms involved in their degeneration are different in these two cortical regions. Furthermore, the survival of CR cells in hippocampal slice cultures may allow the development of approaches aimed at characterizing the role of these neurons in the formation and regeneration of hippocampal connections in vitro.

\section{REFERENCES}

Abercrombie M (1946) Estimation of nuclear population from microtome section. Anat Rec 94:297-247.

Al-Ghoul WM, Miller MV (1989) Transient expression of Alz-50 immunoreactivity in developing rat neocortex: a marker for naturally neuronal death? Brain Res 481:361-367.

Allendoerfer KL, Shatz CJ (1994) The subplate, a transient neocortical structure: its role in the development of connections between thalamus and cortex. Annu Rev Neurosci 17:185-218.

Bayer SA, Altman J (1990) Development of layer I and the subplate in rat neocortex. Exp Neurol 107:48-62.

Bayer SA, Altman J (1991) Neocortical development. New York: Raven.

Berger B, Alvarez C (1996) Neurochemical development of the hippocampus region in the fetal rhesus monkey. III: Calbindin-D28K: calretinin and parvalbumin with special mention of Cajal-Retzius cells and retrosplenial cortex. J Comp Neurol 366:674-699.

Bolz J, Novak N, Staiger V (1992) Formation of specific afferent connections in organotypic slice cultures from rat visual cortex cocultured with lateral geniculate nucleus. J Neurosci 12:3054-3070.

Bradford R, Parnavelas JG, Lieberman AR (1977) Neurons in layer I of the developing occipital cortex of the rat. J Comp Neurol 176:121-132.

Caeser M, Schütz A (1992) Maturation of neurons in neocortical slice cultures: a light and electron microscopic study on in situ and in vitro material. J Hirnforsch 33:429-443.

Caviness Jr VS (1973) Time of neuron origin of the hippocampus and dentate gyrus of normal and reeler mutant mice: an autoradiographic analysis. J Comp Neurol 151:113-120.

Caviness Jr VS (1982) Neocortical histogenesis in normal and reeler mice: a developmental study based upon ${ }^{3}[\mathrm{H}]$ thymidine autoradiography. Dev Brain Res 4:293-302.

Choi DW (1988) Glutamate neurotoxicity and diseases of the nervous system. Neuron 1:623-634.

Chronwall B, Wolff JR (1980) Prenatal and postnatal development of GABA-accumulating cells in the occipital neocortex of rat. J Comp Neurol 190:187-208.

Davies AM (1988) The emerging generality of the neurotrophic hypothesis. Trends Neurosci 11:243-244.

Davies AM (1994) The role of neurotrophins in the developing nervous system. J Neurobiol 25:1334-1348.

D'Arcangelo G, Miao GG, Chen SC, Soares HD, Morgan JI, Curran T (1995) A protein related to extracellular matrix proteins deleted in the mouse mutant reeler. Nature 374:719-723.

De Carlos JA, O'Leary DDM (1992) Growth and targeting of subplate axons and establishment of major cortical pathways. J Neurosci 12:1194-1211.
Del Río JA, Heimrich B, Soriano E, Schwegler H, Frotscher M (1991) Proliferation and differentiation of GFAP-immunoreactive glial cells in organotypic slice cultures of rat hippocampus. Neuroscience 43:335-347.

Del Río JA, Martínez A, Fonseca M, Auladell C, Soriano E (1995a) Glutamate-like immunoreactivity and fate of Cajal-Retzius cells in the murine cortex as identified with calretinin antibody. Cereb Cortex 5:13-21.

Del Río JA, Soriano E, Supèr H, Frotscher M, Heimrich B (1995b) Characteristics and functions of Cajal-Retzius cells in organotypic slice cultures of hippocampus and neocortex. Soc Neurosci Abstr 701:12.

Derer P, Derer M (1990) Cajal-Retzius cell ontogenesis and death in mouse brain visualized with horseradish peroxidase and electron microscopy. Neuroscience 36:839-856.

Derer P, Derer M (1992) Development and fate of Cajal-Retzius cells in vivo and in vitro. In: Development of the central nervous system in vertebrates (Sharma SC, Goffinet AM, eds), pp 113-127. New York: Plenum.

Divac I, Marinkovic S, Mogensen J, Schwerdtfeger W, Regidor J (1987) Vertical ascending connections in the isocortex. Anat Embryol 175:427-446.

Edmunds SM, Parnavelas JG (1982) Retzius-Cajal cells: an ultrastructural study in the developing visual cortex of the rat. J Neurocytol 11:427-446.

Fairén A, Cobas A, Fonseca M (1986) Times of generation of glutamic acid decarboxylase immunoreactive neurons in mouse somatosensory cortex. J Comp Neurol 251:67-83.

Friedman WJ, Olson L, Persson H (1991) Cells that express brainderived neurotrophic factor mRNA in the developing postnatal rat brain. Eur J Neurosci 3:688-697.

Frotscher M, Heimrich B (1993) Formation of layer-specific fiber projections to the hippocampus in vitro. Proc Natl Acad Sci USA 90:10400-10403.

Frotscher M, Heimrich B, Schwegler H (1990) Plasticity of identified neurons in slice cultures of hippocampus: a combined Golgi/electron microscopic and immunocytochemical study. Prog Brain Res 83:323-339.

Frotscher M, Zafirov S, Heimrich B (1995) Development of identified neuronal types and specific synaptic connections in slice cultures of rat hippocampus. Prog Neurobiol 45:143-164.

Gähwiler BH (1981) Organotypic monolayer cultures of nervous tissue. J Neurosci Methods 4:329-342.

Gähwiler BH (1984) Development of the hippocampus in vitro: cell types, synapses and receptors. Neuroscience 11:751-760.

Ghosh A, Shatz CJ (1992) Involvement of subplate neurons in the formation of ocular dominance columns. Science 255:1441-1443.

Ghosh A, Antonini A, McConnell SK, Shatz CJ (1990) Requirement for subplate neurons in the formation of thalamocortical connections. Nature 347:179-181.

Gillies K, Price DJ (1994) Cell migration and subplate loss in explant cultures of murine cerebral cortex. NeuroReport 4:911-914.

Götz M, Bolz J (1992) Formation and preservation of cortical layers in slice cultures. J Neurobiol 23:783-802.

Gravieli Y, Sherman Y, Ben-Sasson A (1992) Identification of programmed cell death in situ via specific labelling of nuclear DNA fragmentation. J Cell Biol 119:493-501.

Hancock MB (1982) DAB-nickel substrate for the differential immunoperoxidase staining of nerve fibers and fiber terminals. J Histochem Cytochem 30:578-580.

Hirotsune S, Takahara T, Sasaki N, Hirose K, Yoshiki A, Ohashi T, Kusakabe M, Murakami Y, Muramatsu M, Watanabe S, Nakao K, Katsuki M, Hayashizaki Y (1995) The reeler gene encodes a protein with an EGF-like motif expressed by pioneer neurons. Nature Genet 10:77-83.

Huntley GW, Jones EG (1990) Cajal-Retzius neurons in developing monkey neocortex show immunoreactivity for calcium-binding proteins. J Neurocytol 19:200-212.

König N, Marty R (1981) Early neurogenesis and synaptogenesis in cerebral cortex. Bibl Anat 19:152-160.

König N, Valat J, Fulcrand J, Marty R (1977) The time of origin of Cajal-Retzius cells in the rat temporal cortex: an autoradiographic study. Neurosci Lett 4:21-26.

Kostovic I, Rakic P (1990) Developmental history of the transient subplate zone in the visual and somatosensory cortex of the macaque monkey and human brain. J Comp Neurol 297:441-470. 
Kostovic I, Seress L, Mrzljak L, Judas M (1989) Early onset of synapse formation in the human hippocampus: a correlation with Nissl-Golgi architectonics in 15- and 16.5-week-old fetuses. Neuroscience 30: 105-116.

Li D, Field PM, Starega U, Li Y, Raisman G (1993) Entorhinal axons project to dentate gyrus in organotypic slice co-culture. Neuroscience 52:799-813.

Li D, Field PM, Yoshioka N, Raisman G (1994) Axons regenerate with correct specificity in horizontal slice culture of the postnatal rat entorhino-hippocampal system. Eur J Neurosci 6:1026-1037.

Liu Y, Fujise N, Kosaka T (1996) Distribution of calretinin immunoreactivity in the mouse dentate gyrus. I. General description. Exp Brain Res 108:389-403.

Luskin MB, Shatz CJ (1985) Studies of the earliest generated cells of the cat's visual cortex: cogeneration of subplate and marginal zones. J Neurosci 5:1062-1075.

Marín-Padilla M (1971) Early prenatal ontogenesis of the cerebral cortex (neocortex) of the Felix domestica. A Golgi study. I. The primordial neocortical organization. Z Anat Entwicklungsgesch 134:117-145.

Marín-Padilla M (1972) Prenatal ontogenic history of the principal neurons of the neocortex of the cat (Felix domestica). A Golgi study. II. Developmental differences and their significances. Z Anat Entwicklungsgesch 136:125-142.

Marín-Padilla M (1984) Neurons of layer I. A developmental analysis. In: Cerebral cortex, Vol I: Cellular components of the cerebral cortex (Peters A, Jones EG, eds), pp 447-478. New York: Plenum.

Marín-Padilla M (1988) Early ontogenesis of the human cerebral cortex. In: Cerebral cortex, Vol VII: Development and maturation of the cerebral cortex (Peters A, Jones EG, eds), pp 1-30. New York: Plenum.

Marín-Padilla M (1990) Three-dimensional structural organization of layer I of the human cerebral cortex: a Golgi study. J Comp Neurol 299:89-105.

Marín-Padilla M, Marín-Padilla MT (1982) Origin, prenatal development and structural organization of layer I of the human cerebral (motor) cortex: a Golgi study. Anat Embryol 164:161-206.

Marty S, Carroll P, Cellerino A, Castrén E, Staiger V, Thoenen H, Lindholm D (1996) Brain-derived neurotrophic factor promotes the differentiation of various hippocampal nonpyramidal neurons, including Cajal-Retzius cells, in organotypic slice cultures. J Neurosci 16:675-687.

Mattson MP, Lee RE, Adams ME, Guthrie PB, Kater SB (1988) Interactions between entorhinal axons and target hippocampal neurons: a role for glutamate in the development of hippocampal circuitry. Neuron $1: 865-876$

McConnell SK, Ghosh A, Shatz CJ (1989) Subplate neurons pioneer the first axon pathway from the cerebral cortex. Science 245:978-981.

Nowakowski RS, Rakic P (1979) The mode of migration of neurons in the hippocampus: a Golgi and electron microscopic analysis in foetal rhesus monkey. J Neurocytol 8:697-718.

Ogawa M, Miyata T, Nakajima K, Yagyu K, Seike M, Ikenaka K, Yamamoto H, Mikoshiba K (1995) The reeler gene-associated antigen on Cajal-Retzius neurons is a crucial molecule for laminar organization of cortical neurons. Neuron 14:899-912.

Oppenheim RW (1991) Cell death during development of the nervous system. Annu Rev Neurosci 14:453-501.

Parnavelas JG, Edmunds SM (1983) Further evidence that Retzius-Cajal cells transform to nonpyramidal neurons in the developing rat visual cortex. J Neurocytol 12:863-871.

Pearlman AL, Snider WD, Osborne PA, Brunstrom JE (1995) Neurotrophin- 4 induces the production of c-fos in specific populations of developing cortical neurons that express trkB. Soc Neurosci Abstr 226:7.

Raedler E, Raedler A (1978) Autoradiographic study of early neurogenesis in rat neocortex. Anat Embryol 154:267-284.

Rakic P (1972) Mode of cell migration to the superficial layers of fetal monkey neocortex. J Comp Neurol 145:61-84.
Rennie S, Lotto RB, Price DJ (1994) Growth-promoting interactions between the murine neocortex and thalamus in organotypic co-cultures. Neuroscience 61:547-564.

Rickmann M, Chronwall BM, Wolff JR (1977) On the development of nonpyramidal neurons and axons outside the cortical plate: the early marginal zone as a pallial anlage. Anat Embryol 151:285-307.

Schwaller B, Bruchwald P, Blumcke I, Celio MR, Hunziker W (1993) Characterization of a polyclonal antiserum against the purified human recombinant calcium binding protein calretinin. Cell Calcium $4: 639-648$.

Shatz CJ, Chun JJM, Luskin MB (1988) The role of the subplate in the development of the telencephalon. In: The cerebral cortex, Vol VII: The development of the cerebral cortex (Jones EG, Peters A, eds) pp 35-58. New York: Plenum.

Silos-Santiago I, Greenlund LJS, Johnson Jr EM, Snider WD (1995) Molecular genetics of neuronal survival. Curr Opin Neurobiol 5:42-49.

Soriano E, Del Río JA, Martínez A, Supèr H (1994) The organization of the embryonic and early postnatal murine hippocampus. I. Immunocytochemical characterization of neuronal populations in the subplate and marginal zone. J Comp Neurol 342:571-595.

Stoppini L, Buchs PA, Muller D (1991) A simple method for organotypic cultures of nervous tissue. J Neurosci Methods 37:173-182.

Supèr H, Soriano E (1994) The organization of the embryonic and early postnatal murine hippocampus. II. Development of entorhinal, commisural and septal connections studied with the lipophilic tracer DiI. J Comp Neurol 344:101-120.

Timmusk T, Belluardo N, Metsis N, Pearsson H (1993) Widespread and developmentally regulated expression of neurotrophin-4 mRNA in rat brain and peripheral tissues. Eur J Neurosci 5:605-613.

Timmusk T, Belluardo N, Pearsson H, Metsis M (1994) Developmental regulation of brain-derived neurotrophic factor messenger RNAs transcribed from different promoters in the rat brain. Neuroscience 328:287-291.

Tuttle R, Schlaggar BL, Braisted JE, O'Leary DDM (1995) Maturationdependent upregulation of growth-promoting molecules in developing cortical plate controls thalamic and cortical neurite growth. J Neurosci 15:3039-3052.

Valverde F, Facal-Valverde MV (1987) Transitory populations of cells in the temporal cortex of kittens. Dev Brain Res 32:283-288.

Valverde F, Facal-Valverde MV (1988) Postnatal development of interstitial (subplate) cells in the white matter of the temporal cortex of kittens: a correlated Golgi and electron microscopic study. J Comp Neurol 269:68-192.

Valverde F, Facal-Valverde MV, Santacana ML, Heredia M (1989) Development and differentiation of early generated cells of sublayer VIb in the somatosensory cortex of the rat: a correlated Golgi and autoradiographic study. J Comp Neurol 290:118-140.

Valverde F, López-Mascaraque L, Santacana M, De Carlos JA (1995a) Persistence of early-generated neurons in the rodent subplate: assessment of cell death in neocortex during the early postnatal period. J Neurosci 15:5014-5024.

Valverde F, De Carlos JA, López-Mascaraque L (1995b) Time of origin and early fate of preplate cells in the cerebral cortex of the rat. Cereb Cortex 5:483-493.

Verney C, Derer P (1995) Cajal-Retzius neurons in human cerebral cortex at midgestation show immunoreactivity for neurofilament and calcium-binding proteins. J Comp Neurol 359:144-153.

Wahle P, Meyer G (1987) Morphology and quantitative changes of transient NPY-ir neuronal populations during early postnatal development of the cat visual cortex. J Comp Neurol 261:165-192.

Woo TU, Beale JM, Finlay BL (1991) Dual fate of subplate neurons in a rodent. Cereb Cortex 1:433-443.

Wood JG, Martin S, Price DJ (1992) Evidence that the earliest generated cells of the murine cerebral cortex form a transient population in the subplate and marginal zone. Dev Brain Res 66:137-140. 